\title{
Russian School of Toponymical Cartography
}

\author{
Herzen Andrey ${ }^{\mathrm{a},} *$, Herzen Olga ${ }^{\mathrm{b}}$, Gordova Yuliana ${ }^{\mathrm{b}}$ \\ ${ }^{a}$ Institute of Geography, Russian Academy of Sciences, gerzen@igras.ru \\ ${ }^{b}$ Institute of Linguistics, Russian Academy of Sciences, gercen.olga09@gmail.com,gordova@iling-ran.ru \\ * Corresponding author
}

\begin{abstract}
The development of toponymical cartography in Russia has a long history and rich practical experience. Cartographic methods have been used in toponymical research for many decades. Their great importance was noted by the founders of fundamental place-name study. This field is actively developing despite the considerable methodological complexity and labor intensity. Modern technologies in cartography make it possible to bring the scale and intensity of toponymic research to a new level and solve problems that have long been identified in science. This further increases the relevance of toponymic mapping and the active introduction of other techniques into the practice of local and regional toponymic research.
\end{abstract}

Keywords: Place-Name Study, Toponymy, Cartography, Russia

\section{Introduction}

Toponymy is a collection of place names. People encounter them all the time, in their everyday lives even if they do not travel outside their city. Intraurban names, such as the names of streets, squares, districts are also a kind of toponyms. In fact, the main function of toponyms is the address function. That is the reason why they arise, exist, and are used. Despite the apparent ease, especially for beginners, toponymic studies are quite complicated. This complexity is related to the fact that toponymy, the science of place names, is based on three major scientific conglomerates at once: geography, history, and philology. Toponyms name geographical features, evolve over time, and are linguistic units. Their emergence and development are influenced by the laws of the abovementioned sciences. This requires the researcher to be versed in all three, which is not easy. That is why there are very few professional toponymists, who are always first and foremost geographers, linguists or historians. Cartographers specialize in toponymic issues even more rarely. Most often, their interest is focused on toponymic problems in cartography (mapping toponyms, transcribing them when transferring from one language to another), rather than on the cartographic problems of toponymy itself.

\section{History and outstanding representatives}

The very idea of linguistic mapping belongs to I.I. Sreznevsky (1812-1880). It was realized in 1915 in the "Experience of the Dialectological Map of the Russian Language in Europe" by N.N. Durnovo (18761937), N.N. Sokolov (1875-1923) and D.N. Ushakov (1873-1942). Later another prominent linguist R.I. Avanesov (1902-1982) developed the foundations of the theory of mapping in connection with the creation of the "Dialectological Atlas of the Russian Language" (1962). The fundamental provisions of this theory were taken into account while creating the "Common Slavic Linguistic Atlas" (published since 1958), which demonstrates the spread of linguistic phenomena in Slavic languages. The possibility of using cartographic methods in relation to toponymic material and the significance of such work are described by such founders of Russian place-name study as E.M. Pospelov, E.M. Murzaev, A.V. Superanskaya, V.A. Zhuchkevich, as well as other outstanding Soviet scientists.

The foundations of toponymy as a fundamental science were laid in the middle of the last century, when the Toponymic Commission was established within the Moscow branch of the Geographical Society of the USSR, bringing together scientists from academic institutions (Institute of Geography, Institute of Linguistics, etc.), university teachers and representatives of research institutions. For more than 40 years the Toponymic Commission was headed by E.M. Pospelov, the most prominent scientist in the world toponymy. Other great researchers, such as E.M. Murzaev from the Institute of Geography, A.V. Superanskaya from the Institute of Linguistics, as well as V.A. Nikonov, N.I. Tolstoy, V.N. Toporov, O.N. Trubachyov, G.P. Bondaruk, N.V. Podolkaja, Z.V. Rubtsova, E.M. Smorgunova, M.N. Morozova, F.L. Ageenko and many other outstanding scientists have left us a colossal legacy of their meticulous work (published in author's editions, or collections, special issues of the Problems of Geography series). At the same time, research work was carried out in many scientific centres of the Soviet Union. Kiev, Minsk, Volgograd, Tambov, St. Petersburg, Veliky Novgorod, Petrozavodsk, Yekaterinburg, Ulan-Ude and other cities are important centres of toponymic research. The representatives of the regional schools are well known both in Russia and abroad. The Toponymic Commission is actively working in the capital; it is headed by the largest toponymist of the country, Professor A.V. Barandeev. Thematic symposia and large regional forums are regularly held, and students' conferences on toponymy have been held annually for 
more than half a century (the 56th conference was held in 2021).

\subsection{Eduard Makarovich Murzaev (1908-1998)}

Classical toponymists are unanimous in assessing the role of geographical maps for place-name study. E.M. Murzaev rightly noted: if the author of a particular article can afford to highlight in the text what the knows well, or alternatively keep silent about the unknown, the map in its turn requires the comparability of the whole material presented. Therefore, the map is always more objective and visual than the text. Murzaev highly appreciated the potential of combining the efforts of cartography and place-name study: the cartographic method in toponymic research allows one to clearly show the distribution of certain models of geographical names, the geography of toponymic suffixes, the areas of prevailing languages in modern toponymy, semantic shifts in folk geographic terminology that forms proper names, their connection with natural, social, economic phenomena and objects, density of names or repetition of toponyms per unit area, degree of knowledge, etc. The cartographic method is certainly very laborious and requires the performers to summarize the results obtained as a result of processing mass material. Thus, the cartographic method significantly helps to understand the distribution of toponymic facts and identify patterns (Murzaev 1982).

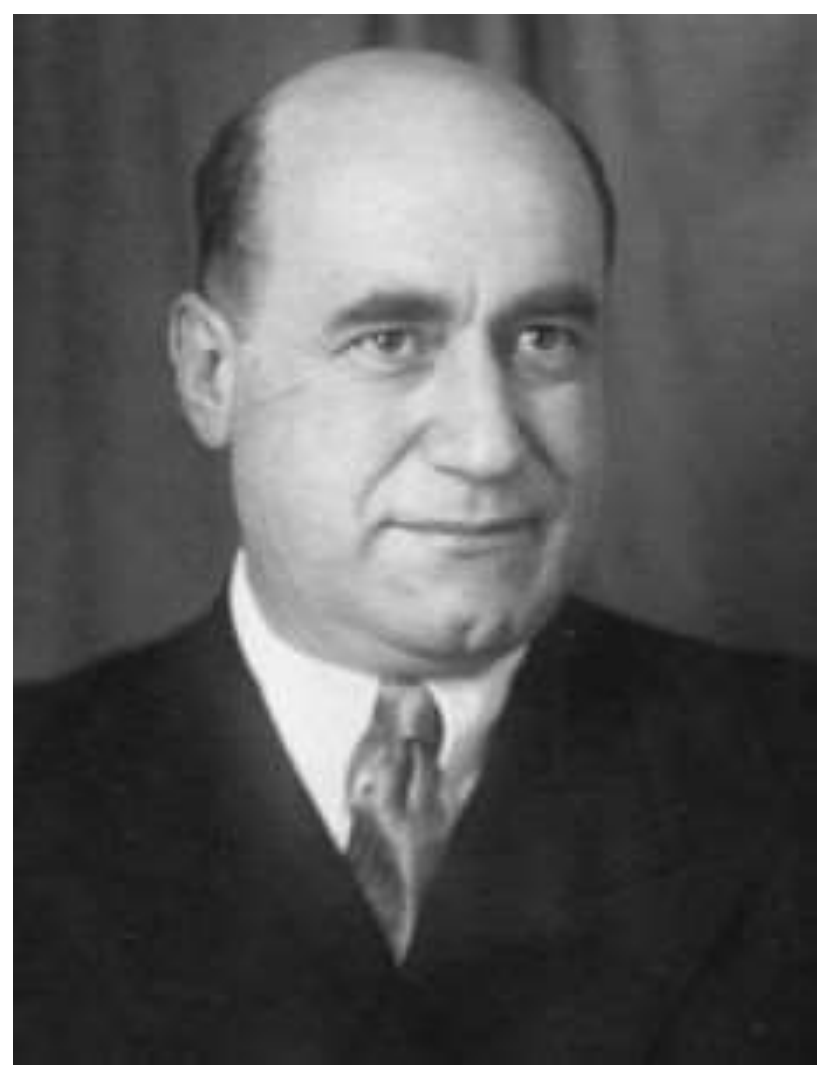

Figure 1. Portrait of E.M. Murzaev.

Murzaev's major contribution to the toponymic science was the creation of a unique dictionary of folk (local) geographical terms, unparalleled in the profoundness of theoretical analysis and spatial coverage (Murzaev, Murzaeva 1959; Murzaev 1984; Murzaev 1999).

\subsection{Vadim Andreevich Zhuchkevich (1915-1985)}

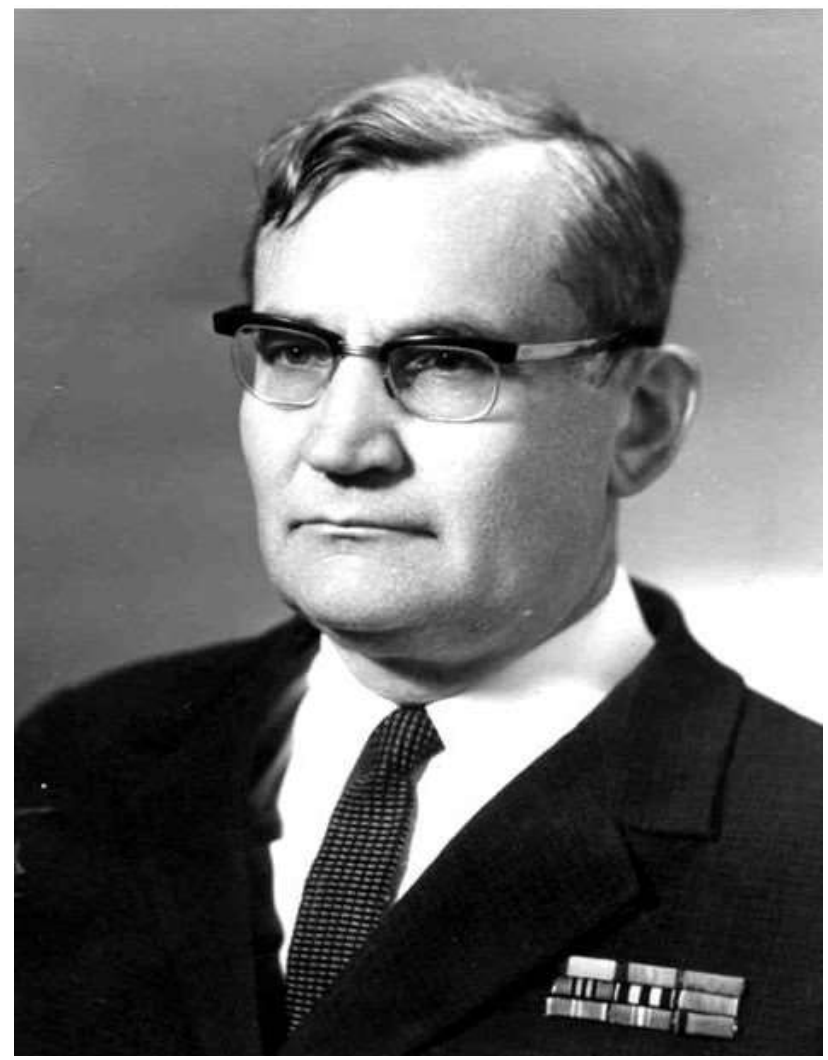

Figure 2. Portrait of V.A. Zhuchkevich.

Without a map, the study of toponymy may turn out to be incomplete, - wrote V.A. Zhuchkevich. He noted that in practice, mapping of the following names is carried out: a) individual names, which are the objects of special toponymic research; b) names, grouped according to grammatical features; c) names united on a national genetic basis; d) commemorative names; e) names by the time of their occurrence; f) toponymic layers; g) the semantic meaning of names and terms; $h$ ) pronunciation of names, etc. (Zhuchkevich 1968a).

Along with the development of the general methodology, landscape and historical-geographical approach in toponymic studies, V. A. Zhuchkevich made the greatest contribution to the study of the toponymy of his native Belarus, having published numerous articles, as well as several books and dictionaries on regional problems (Zhuchkevich 1968b; 1974).

\subsection{Evgeniy Mikhailovich Pospelov (1923-2007)}

E.M. Pospelov fundamentally studied the interaction of place-name study and cartography, developed the problems of toponymical cartography at a new level and created the scientific direction of cartographic place- 
name study, which he defined as a place-name study section serving cartography. According to Pospelov, cartographic place-name study is responsible for the development of principles and specific rules for the transfer of names from one language to another, including the choice of the original form and the definition of the language of transmission; principles and rules for the transfer of names on historical maps and on maps published in national languages; methods of analysis and systematization of names, as well as assessment of the toponymic content of maps. Pospelov emphasized that the content of cartographic place-name study is limited to the range of cartographic tasks that cannot be correctly solved without the involvement of place-name study. He argued that a cartographic image favorably differs from a textual presentation by the visibility and measurability of the information it communicates. Under otherwise equal conditions (time of creation, details, etc.), cartographic sources are usually saturated with geographic nomenclature to a greater extent than literary monuments and documents. Pospelov attached great importance to thematic, special and old maps as a source of geographical names and geographical data necessary to understand the origin, distribution and development of toponymic phenomena. Using a number of maps, created at different times for the same territory, makes it possible to trace the changes that have occurred over time in geographical names, to reveal the dynamics of toponymic phenomena (Pospelov 1971).

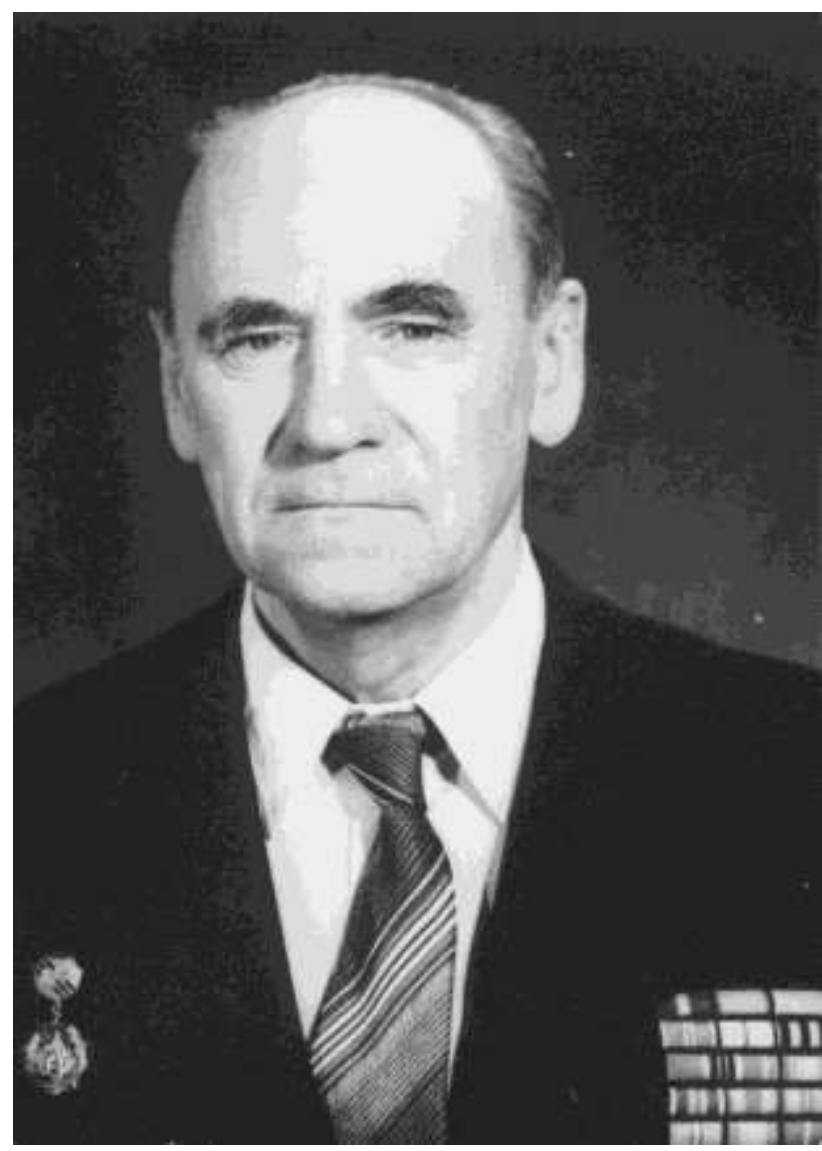

Figure 3. Portrait of E.M. Pospelov.
E.M. Pospelov made a tremendous contribution not only to the development of toponymic cartography but is also rightfully considered the greatest toponymist of the Russian school. The toponymic dictionaries created by him, the materials for which he collected throughout his life, remain unsurpassed in the outreach and depth of study, the level of scientific systematization, geographical, historical and philological argumentation and therefore etymological analysis not only in Russian science, but also worldwide (Pospelov 2007; 2008).

\subsection{Alexandra Vasilievna Superanskaya (1929-2013)}

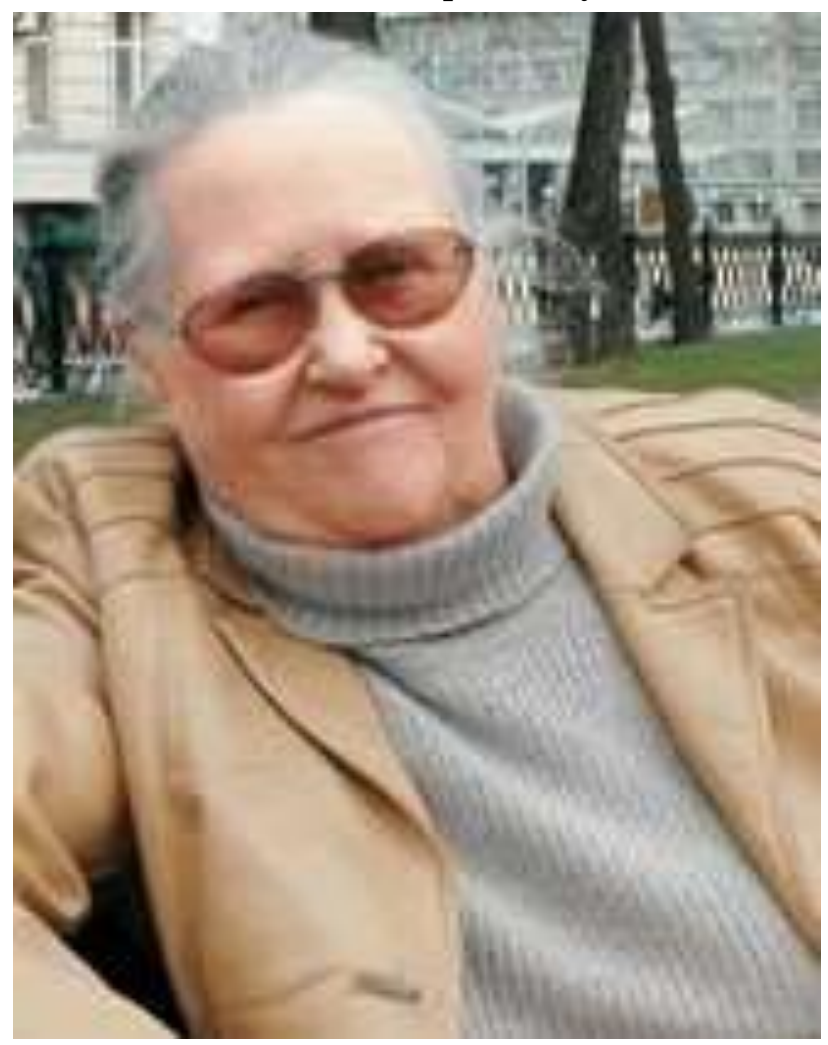

Figure 4. Portrait of A.V. Superanskaya.

The importance of mapping in toponymy has been repeatedly emphasized by theorists of onomastic research, linguists and geographers. The largest representative of the linguistic school is A.V. Superanskaya. In her works, she emphasized that the establishment of onomastic areas is inseparable from another scientific and technical method - mapping, which includes the precise localization of places of settlement of people, in whose speech the studied onomastic phenomenon is noted, or places (cities, towns, rivers, etc.), named in a certain way. However, mapping is used not only to fix the identified areas. Different territorial distributions of names in regional studies and features globally inherent in names of different languages can be mapped. Onomastic mapping cannot be a direct copy of a geographic technique since it is based on a dialectological approach to the presentation of material. Geographers are only supposed to provide a map with the linguistic 
information to be applied. However, by mapping linguistic data, we often obtain extralinguistic inferences that serve to validate historical concepts. Obviously, this is the dialectic of interconnection, mutual assistance and mutual enrichment of the social sciences. And vice versa, maps created by geographers, astronomers, botanists are used by onomasts to collect their own, linguistic, material and to support it with extralinguistic data. This onomastic material, after appropriate processing, can be again put on another, special onomastic map and in this form be of interest not only for linguists, but also for specialists in other fields (Superanskaya et al. 2009).

A.V. Superanskaya is a major Russian theorist of fundamental toponymy, onomastics and applied linguistics, a world-renowned scholar (Superanskaya 1973; 2009).

\subsection{Trends in mapping in the $1970 \mathrm{~s}$ and early $2000 \mathrm{~s}$.}

The cartographic and areal methods were most actively used in the works of Russian toponymists in the 1970s and 1980s. They carried out studies aimed at identifying the areas of Slavic and substrate toponymy of Russia and the Slavic world. The object of research and mapping by G.P. Smolitskaya was the toponymy of Upper and Middle Pooch'e (Smolitskaya 1976), while Z.V. Rubtsova first studied and mapped the Slavic toponyms of the Belorussian territory, and then of the whole East Slavic territory (Rubtsova 1974, 1980). P. Chumakova was involved in determining the areal extent of the Old Russian toponymic types in the Middle Oka area (Chumakova 1992). In late 1980s - early 2000s an important contribution to the development of the toponymic mapping was made by A.K. Matveev (Matveev 1986, 2001-2015). He prepared a manuscript of the Atlas of Substrate Toponymy of the Russian North (Matveev 2001, p. 11).

\subsection{Galina Petrovna Smolitskaya (1926-2006)}

G.P. Smolitskaya is the author of several fundamental and landmark works for Russian toponymy, first of all, "The Hydronymy of the Oka Basin. List of Rivers and Lakes" catalogue and "The Toponymic Dictionary of Central Russia" (Smolitskaya 1976; 2002). In the 1970s and 1980 s, she was directly involved in the development of the concept for the Toponymic Atlas of the Centre, conceived by E. M. Pospelov, and in the preparation of the first maps for this atlas. She published maps of the distribution of local geographical terms (in particular, kor' / korek, losk, loščina, veršina) on the territory of Central Russia. Smolitskaya also developed theoretical provisions on the correlation between the ranges of Slavic appellatives and toponyms and worked out practical recommendations for mapping (Smolitskaya 1970; 1972; 1974).

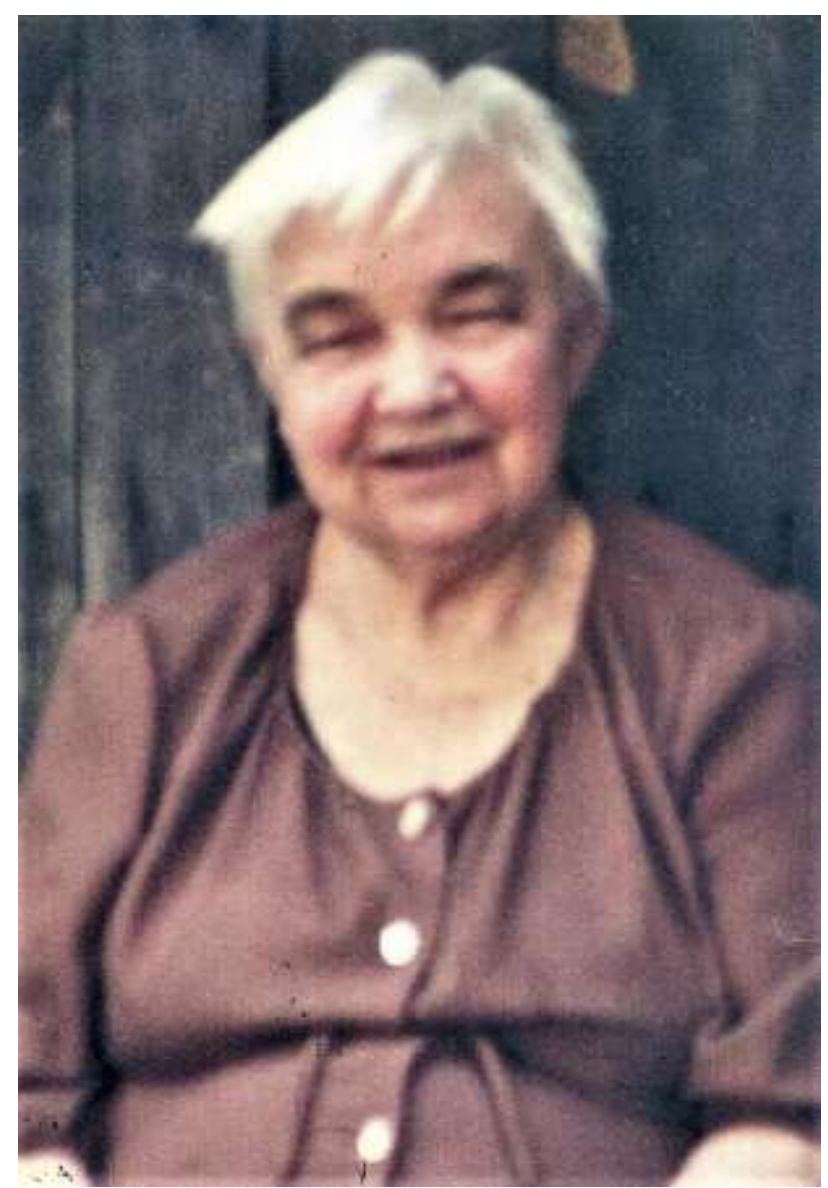

Figure 5. Portrait of G.P. Smolitskaya.

\section{Contemporary researchers and tendencies}

\subsection{Outstanding modern Russian toponymical works and new tendencies}

A.V. Postnikov (1980), V.D. Belenkaya (1980), R.A. Ageeva (1985), A.V. Barandeev (2005, 2017) and other researchers devote a lot of attention to cartographic sources and the historic-geographical approach in placename study. The largest representative of the Finno-Ugric trend in toponymic mapping is I.I. Mullonen (1988, 2002, 2008). She has created electronic maps of Karelian toponymy (Mullonen, Kuzmin 2008).

Modern researchers note an increased interest in placename study at a new stage in the development of cartographic technologies. In recent years, a kind of "renaissance" of toponymical research has been taking place in the scientific community of geographers, who pay significantly increased attention to this scientific field. Cartography and place-name study are two sciences that, in addition to their borderline position in geography, can also be characterized as cross-cutting for it, i.e. covering the entire family of geographical sciences, without which none of them can do (Afanasyev 2007). The creation of modern databases of toponyms, electronic gazetteers, and the use of GIS technologies will significantly intensify toponymic research (Basik 2008). 
We can single out the following latest research related to toponymic cartography: a) toponymic models of South Karelia (Syamozerie) (Afanasyeva 2019; it is important to note that the researcher continues and develops the ideas of the Karelian onomast I.I. Mullonen on obligatory mapping of the focus toponymic material); b) method for locating ancient toponyms of the Novgorod land (Ankudinov 2019); c) reconstruction of the PolishLithuanian Commonwealth resident's route of movement, as well as replication of the internal planning of Warsaw and Krakow (Bogatyrev 2019); d) reconstruction and establishment of the location of the ancient names of wastelands and settlements, toponyms mentioned in medieval books (Gordova 2019); e) poly-scale toponymic research in historical geography and cartography, the study of transferred toponyms and toponymic repressions phenomena (Herzen 2018, 2019, 2020, Herzen et al. 2021) and other works.

\subsection{Poly-scale toponymic research in historical geography and cartography}

Toponyms represent an integral part of intangible cultural heritage, one of the most enduring and at the same time fragile ones. They have a very important address function and therefore play an enormous role in the life of people and human communities throughout history. They are formed in historical and geographical landscapes under the influence of a variety of natural and cultural factors, in a specific linguistic and ethnic environment. The toponymic component (toponymic landscape) is the most important indicator of the landscape, and the historical and geographical reconstruction of the stages of its development allows to understand its evolution, to identify landscape-forming elements, valuable heritage sites, the basis of sustainability of multicomponent complexes, in which modern socio-economic and cultural systems exist.

Cartographic methods serve as the cornerstone of the historical-geographical approach. Its application within the framework of integrated multiscale studies allows to solve scientific problems arising in the systematization of knowledge about natural and cultural heritage. Only within the framework of an integrated historicalgeographical approach is it possible to identify and understand the structure of the toponymic landscape (Herzen 2020, 2021). This is proven by the results of research into the phenomenon of transferred toponyms. They represent a unique geographical phenomenon that stores extremely interesting and useful historical and linguistic information, and in their totality form the basis of the toponymic component of the historicalgeographical landscape.

Application of the cartographic method for their systematization and analysis allows us to talk about the explicable arrangement of toponyms, historically and geographically determined by migrations of the native carriers of the modeled and recorded in memory component of the historical and geographical landscape, reproduced in the process of development of new places of settlement - toponymic landscape (Herzen 2018). This is clearly reflected in the material of toponyms with the bases of Moldav-/Moldov- in Central Europe (from the Alps to the Baltic and the Black Sea coast) and in the material of Slavic toponyms Pereyaslavl, Trubezh, Zvenigorod, etc. in the Russian Plain (Paskary 2014; Paskary, Herzen 2016; Herzen 2018, 2021; Herzen et al. 2019).

\subsection{Experience with regional toponymic maps and atlases}

Today, the development of toponymic cartography is one of the urgent tasks of modern onomastics, especially in connection with the plans to create a Toponymic Atlas of Russia and regional toponymic atlases, which are considered as constituent elements of the all-Russian atlas and stages of the implementation of this project. The first monograph, the Toponymic Atlas of the Ryazan Region (Gordova 2015), was published in 2015; a group of scientists from the Institute of Linguistics of the Russian Academy of Sciences and the Institute of Archeology of the Russian Academy of Sciences has been working to create a toponymic atlas of the Tambov region since 2020. Despite the undeniable value and effectiveness of the cartographic method, we should recognize that it is used very rarely in regional toponymic studies, mainly due to the technical difficulties and the seeming laboriousness of the process of creating a map.

The developed methodology of compiling the toponymic atlas is aimed at creating a series of maps showing the zones of distribution of various toponymic phenomena (toponyms of a certain structural type, certain topographic bases, topoformants, topolexemes, toponymic models). When considering toponymy chronologically, maps are made for each historical period: pre-Slavonic, Old Russian, Middle Russian, modern. At the same time, the objects of mapping are "the phenomena and processes occurring in time and changing the toponymic system; such maps show, in particular, the disappearance of old and the appearance of new formants, the replacement of productive formant types, models, changes in the share of toponyms of the group under study (for example, those associated with Christian culture) in the total toponymy of the region" (Gordova 2020: 54).

The methodology of creating a toponymic atlas of the region includes several stages: 1) compilation of a catalogue of geographical names of the region; 2) grouping of names by language affiliation, then by type, to make separate map layers; 3) mapping the identified groups of toponyms; 4) delineation of the areal and 'splash' of the areal; 5) description and characterization of the areal; 6) linguistic interpretation of the material, 
taking into account the etymology and structuralsemantic characteristics of the mapped toponyms; 7) combining the identified areas with the areas of nonlinguistic phenomena (archaeological, geographical, historical) and similar toponymic areas of other regions; 8) chronological and ethno-cultural attribution; 9) drawing conclusions or making hypotheses about the phenomenon mapped. The experience of creating a regional toponymic atlas is described in detail in the monograph "Current methods of processing and presenting onomastic data: 2009-2019" (Gordova 2015: 48-74). The examples of the developed toponymic maps for the regional atlas are presented in Fig. 6, 7.

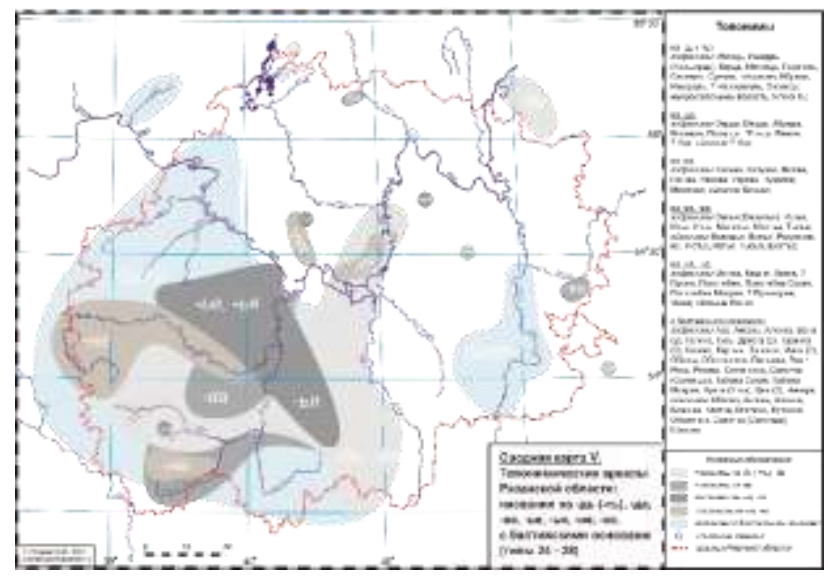

Figure 6. Toponymic areals of the Ryazan region (Gordova 2014).

\subsection{Prospects for further research}

The traditions of the Russian school of cartography could be preserved by creating a special research group and organizing seminars on toponymic cartography at Russia's leading linguistic institute - the Institute of Linguistics of the Russian Academy of Sciences (Moscow). This would contribute to the development and more active implementation of cartographic methods in the practice of onomastic research.

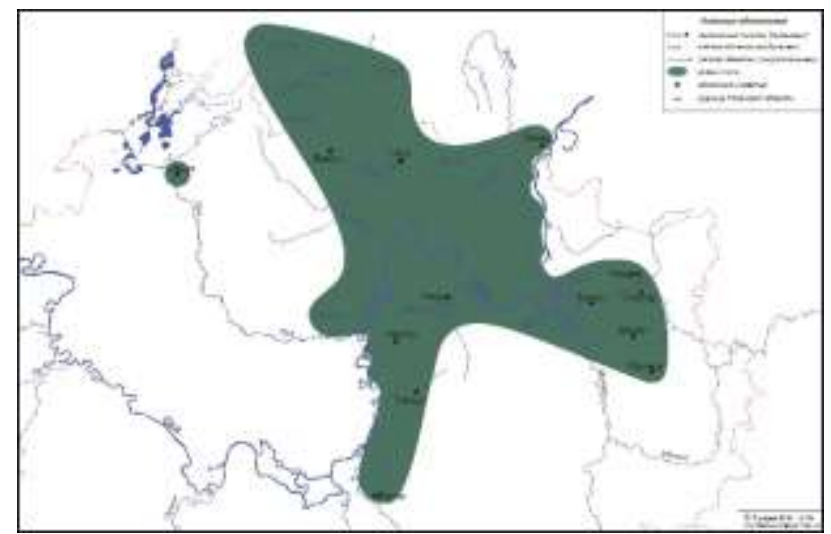

Figure 7. Toponyms ending in - $u r$ of the Ryazan region (Gordova 2014).

\section{Conclusions}

The Russian toponymic school, one of the largest in the world, is based on the achievements of the scientists of the second half of the 20th century, who contributed greatly to the development of the toponymic cartography. Modern researchers continue the work of their teachers, although the task of toponymic mapping is faced with objective difficulties because of the immense size of the country, the high diversity of its toponymic landscapes, and the enormous labor intensity of the process.

The developed methodology of making maps of the toponymic atlas of the region can be applied to other regions, as well as to the territory of Russia as a whole, which brings us closer to the implementation of the idea of the 1970s classics of Russian toponymic mapping by E.M. Pospelov and G.P. Smolitskaya to create a Toponymic Atlas of the Center of Russia. Creation of special courses on toponymic mapping will help to enhance the work in this direction.

The use of geographical, linguistic and archaeological methods increases the efficiency of research and makes the conclusions more meaningful and profound. It also encourages interdisciplinary integration and knowledge consolidation from different areas of science for the sake of getting closer to the truth.

\subsection{Acknowledgements}

The study was carried out with the financial support of the Russian Foundation for Basic Research in the framework of the Research Project No. 19-05-00533 A.

\section{References}

Afanasyev, O.E., 2007. Kartografija i toponimika: metodologija regional'nogo pohoda $\mathrm{k}$ izucheniju. In: Pskovskij regionologicheskij zhurnal, Pskov, Russia, №4, pp. 99-110 (in Russian).

Afanasyeva, A.A., 2019. Areal'naja distribucija karel'skih toponimnyh modelej v Sjamozer'e In: Onomastika Povolzh'ja, Velikij Novgorod, Russia, pp. 154-158 (in Russian).

Ageeva R.A., 1985. Proishozhdenie imen rek i ozer. Moscow, USSR (in Russian).

Ankudinov, I.Ju., 2019. O lokalizacii toponimov novgorodskih pozemel'nyh aktov XII-XV vv. In: Onomastika Povolzh'ja, Velikij Novgorod, Russia, pp. 118-120 (in Russian).

Avanesov, R.I., 1962. Dialectological Atlas of the Russian Language. Moscow, USSR (in Russian).

Barandeev, A.V., 2017. Istorija geograficheskih nazvanij. Russkaja toponimija v terminah. 4 ed. Moscow, Russia (in Russian). 
Barandeev, A.V. 2018. Kratkij jetimologicheskij toponimicheskij slovar'. 2 ed. Moscow, Russia (in Russian).

Basik, S.N., 2008. Obshhaja toponimika. Minsk, Byelorussia (in Russian).

Belenkaya, V.D., 1980. Starye geograficheskie karty kak toponimicheskij istochnik (na materiale toponimii SShA). In: Ispol'zovanie staryh kart v geograficheskih $i$ istoricheskih issledovanijah, Moscow, USSR, pp. 42-65 (in Russian).

Bogoyavlenskiy, S.K. and Golubtsov, I.A., 1952. Moskva okolo serediny XVII veka (karta). In: Istorija Moskvy. Prilozhenie $k$ pervomu tomu. Plany, Moscow, USSR (in Russian).

Chumakova, Ju.P., 1992. Rasselenie slavjan v Srednem (Rjazanskom) Pooch'e po lingvisticheskim i istoricheskim dannym. Ufa, Russia (in Russian).

Common Slavic Linguistic Atlas. 1958-. Moscow, USSR/Russia (in Russian).

Durnovo, N.N., Sokolov, N.N. and Ushakov D.N., 1915. Experience of the Dialectological Map of the Russian Language in Europe. Saint-Petersburg, Russia (in Russian).

Gorbanevskiy M.V., 1987. V mire imjon i nazvanij. 2 ed. Moscow, USSR (in Russian).

Gordova, Yu.Yu., 2020. Aktual'nye sposoby obrabotki i predstavlenija onomasticheskih dannyh: 2009-2019. Moscow, Russia (in Russian).

Gordova, Yu.Yu., 2019. Onomasticheskaja rekonstrukcija: vosstanovlenie i lokacija toponimii predydushhego hronologicheskogo sloja po nazvanijam srednevekovyh pustoshej, gorodishh, selishh (rjazanskij material). In: Rhema. Rema, Moscow, Russia, № 4, pp. 53-69 (in Russian).

Gordova, Yu.Yu., 2015. Toponimicheskij atlas Rjazanskoj oblasti. Moscow, Russia (in Russian).

Herzen, A.A., 2018. Historic-geographical context of transferred toponyms. In: Problems of Geography, No 146, Moscow, Russia, pp. 27-73 (in Russian).

Herzen, A.A., 2020. Cartographic Methods for Solving Historical and Geographical Problems (on the Example of Multiscale Research of Europe, Mediterranean and North-Western Black Sea Regions). In: InterCarto. InterGIS, V. 26, Part 4, Moscow, Russia, pp. 266-281 (in Russian). DOI: 10.35595/2414-9179-2020-4-26-266281.

Herzen, A.A., 2020. Old Maps of the Northern Black Sea Region and the Cartographic Approach in Solving Historic-Geographical Tasks. In: Socio-Natural History, Vol. 43, Moscow, Russia, pp. 13-25 (in Russian). DOI: 10.29003/m1940.s-n_history_2020_43/13-25.
Herzen, A.A., 2021. Geopolitical and HistoricGeographical Problems of the Black Sea Region (Review of Results of International Conference 2019). In: Izv. RAN. Ser. geogr., T. 85, № 1, Moscow, Russia, pp. 146155 (in Russian). DOI: 10.31857/S2587556621010040.

Herzen A., 2021. The historical-geographical context of transferred toponyms. In: Place Names and Migration. Proceedings of the Symposium in Vienna, 6-8 November 2019 (= Name \& Place, Vol. 9) / Dollimore, A. and Jordan, P. (eds.). Hamburg, Germany, pp. 273-283.

Herzen, A.A., Nesterova, T.P., Paskary, E.G. and Tel'nov N.P., 2019. At the crossroads of civilizations: space, time, heritage. Newest historic-geographical researches of some monuments of the North-Western Black Sea Region. Moscow - Saint Petersburg, Russia (in Russian).

Herzen, A.A., Paskary E.G. and Khropov A.G., 2021. Topographic Maps of the North-Western Black Sea Region of the 17th to Mid - 18th Centuries. In: Geodesy and Cartography = Geodezia $i$ Kartografia, 82(6), Moscow, Russia, pp. 26-36 (in Russian). DOI: 10.22389/0016-7126-2021-972-6-26-36.

Matveev, A.K., 1986. Metody toponimicheskih issledovanij. Sverdlovsk, USSR (in Russian).

Matveev, A.K., 2006. Onomatologija. Moscow, Russia (in Russian).

Matveev, A.K., 2001-2015. Substratnaja toponimija Russkogo Severa, in 4 vol. Ekaterinburg, Russia (in Russian).

Mullonen, I.I., 1988. Gidronimija bassejna reki Ojati. Petrozavodsk, USSR (in Russian).

Mullonen, I.I. and Kuz'min D.V., 2008. Granicy toponimnyh arealov Karelii. Materialy atlasa In: Granicy $i$ kontaktnye zony $v$ istorii $i$ kul'ture Karelii $i$ sopredel'nyh regionov. Gumanitarnye issledovanija, Vyp. 1. Petrozavodsk, Russia, pp. 215-256 (in Russian).

Mullonen, I.I., 2002. Toponimija Prisvir'ja: Problemy jetnojazykovogo kontaktirovanija. Petrozavodsk, Russia (in Russian).

Mullonen, I.I., 2008. Toponimija Zaonezh'ja: Slovar' s istoriko-kul'turnymi kommentarijami. Petrozavodsk, Russia (in Russian).

Murzaev, Je.M., 1959. Murzaeva V.G. Slovar' mestnyh geograficheskih terminov. Moscow, USSR (in Russian).

Murzaev, Je.M., 1982. Geografija v nazvanijah. 2 ed. Moscow, USSR (in Russian).

Murzaev, Je.M., 1984. Slovar' narodnyh geograficheskih terminov. Moscow, USSR (in Russian).

Murzaev, Je.M., 1999. Slovar' narodnyh geograficheskih terminov. 2 ed., in 2 vol. Moscow, Russia (in Russian). 
Murzaev, Je.M., 2001. Slovo na karte. Moscow, Russia (in Russian)

Nesterova, T.P. and Herzen, A.A., 2021. Architectural and Historic-Geographical Mystery of the Church of Vasilkeu Village. In: Revista Arta, vol. XXX, № 1, Kishinev, Moldavia, pp. 156-164 (in Russian). DOI: 10.52603/arta.2021.30-1.20.

Nikonov, V.A., 1965. Vvedenie v toponimiku. Moscow, USSR (in Russian).

Nikonov, V.A., 1966. Kratkij toponimicheskij slovar'. Moscow, USSR (in Russian).

Paskary, E.G., 2014. Unknown Moldavia. Odessa, Ukraine (in Russian).

Paskary, E.G. and Herzen, A.A., 2016. Toponym Moldavia: ancient recollections and new etymologies. In: Rusin, No 1 (43), Kishinev, Moldavia, pp. 9-35 (in Russian). DOI: 10.17223/18572685/43/2.

Piscovye knigi Rjazanskogo kraja XVI v. / Storozhev, V.N. (ed.), 1996, V. 1, 2 ed., T. I, Rjazan', Russia (in Russian).

Podolskaya, N.V., 1988. Slovar' russkoj onomasticheskoj terminologii. 2 ed. Moscow, USSR (in Russian).Pospelov, E.M., 1971. Toponimika i kartografija. Moscow, USSR (in Russian).

Pospelov, E.M., 2007. Illjustrirovannyj atlas mira. Geografija mira: novejshij toponimicheskij slovar': ok.8000 ed. Moscow, Russia (in Russian).

Pospelov, E.M., 2008. Geograficheskie nazvanija Moskovskoj oblasti: toponimicheskij slovar': bolee 3500 ed. Moscow, Russia (in Russian).

Postnikov, A.V. and Mel'nikova, E.B., 1980. Karty i soputstvujushhie im materialy XVIII-XIX vv. kak istochniki dlja izuchenija izmenenij prirodnoj sredy Central'noj Rossii In: Ispol'zovanie staryh kart $v$ geograficheskih $i$ istoricheskih issledovanijah, Moscow, USSR, pp. 42-65 (in Russian).

Problems of Geography, No 58: Geograficheskie nazvanija / Murzaev, Je.M. and Nikonov, V.A., 1962. Moscow, USSR (eds.), (in Russian).

Problems of Geography, No 70: Izuchenie geograficheskih nazvanij / Murzaev, Je.M. and Nikonov, V.A. (eds.), 1966. Moscow, USSR (in Russian).

Problems of Geography, No 81: Mestnye geograficheskie terminy / Pospelov, E.M. and Tolstoy, N.I. (eds.), 1970. Moscow, USSR (in Russian).

Problems of Geography, No 94: Toponimija Central'noj Rossii / Pospelov, E.M. (ed.), 1974. Moscow, USSR (in Russian).

Problems of Geography, No 110: Toponimika na sluzhbe geografii / Pospelov, E.M. (ed.), 1979. Moscow, USSR (in Russian).
Problems of Geography, No 126: Geograficheskie nazvanija v Moskve / Pospelov, E.M. (ed.), 1985. Moscow, USSR (in Russian).

Problems of Geography, No 132: Sovremennaja toponimika / Barandeev, A.V., Ageeva, R.A., Herzen, A.A. (eds.), 2009. Moscow, Russia (in Russian).

Problems of Geography, No 146: Aktual'nye problemy toponimiki / Kotljakov, V.M., Barandeev, A.V., Ageeva, R.A., Herzen, A.A. (eds.), 2018. Moscow, Russia (in Russian).

Rubtsova, Z.V., 1974. Belorusskij areal toponimov s final'ju -n' In: Aspekty lingvisticheskogo analiza. Na materiale jazykov raznyh sistem, Moscow, USSR, pp. 318-327 (in Russian).

Rubtsova, Z.V., 1980. Toponimicheskaja final' -n' na vostochnoslavjanskoj territorii (sinhronnoe sostojanie) In: Perspektivy razvitija slavjanskoj onomastiki, Moscow, USSR, pp. 125-141 (in Russian).

Russkij jazyk: Jenciklopedija / Karaulov, Ju.N. (ed.), 2003. Moscow, Russia (in Russian).

Smolitskaya, G.P., 1970. Geograficheskij termin kor' korjok In: Problems of Geography, No 81: Mestnye geograficheskie terminy / Pospelov, E.M. and Tolstoj, N.I. (eds.), Moscow, USSR, pp. 145-150 (in Russian).

Smolitskaya, G.P., 1972. Gidronimija v Toponimicheskom atlase Centra. In: Toponimija Centra (tezisy dokladov) / Pospelov, E.M. (ed.). Moscow, USSR, pp. 9-10 (in Russian).

Smolitskaya, G.P., 1974. Kartografirovanie gidronimii Pooch'ja In: Problems of Geography, No 94: Toponimija Central'noj Rossii, Moscow, USSR, pp. 59-69 (in Russian).

Smolitskaya, G.P., 1976. Gidronimija bassejna Oki (Spisok rek i ozjor). Moscow, USSR (in Russian).

Smolitskaya, G.P., 2002. Toponimicheskij slovar' Central'noj Rossii. Moscow, Russia (in Russian).

Superanskaya, A.V., 1973. Obshhaja teorija imeni sobstvennogo. Moscow, USSR (in Russian).

Superanskaya, A.V., Staltmane, V.Ye., Podolskaya, N.V. and Sultanov, A.H., 2009. Teorija i metodika onomasticheskih issledovanij / Nepokupnyj, A.P. (ed.), 3 ed., Moscow, Russia (in Russian).

Voprosy teorii lingvisticheskoj geografii / Avanesov, R.I. (ed.), 1962. Moscow, USSR (in Russian).

Zhuchkevich, V.A., 1974. Kratkij toponimicheskij slovar' Belorussii. Minsk, USSR (in Russian).

Zhuchkevich, V.A., 1968. Obshhaja toponimika. 2 ed. Minsk, USSR (in Russian).

Zhuchkevich, V.A., 1968. Toponimika Belorussii. Minsk, USSR (in Russian). 